\title{
Kelola
}

\section{Pengaruh Budaya Organisasi Dan Komunikasi Interpersonal Terhadap Sikap Kerja Guru SMP Swasta}

\author{
Elfridauli \\ Pascasarjana Manajemen Pendidikan Universitas Negeri Jakarta \\ elfrida@tbcs.sch.id
}

\begin{abstract}
The purpose of this study is to determine the influence of organizational culture and interpersonal communication on the work attitude of private junior high school teachers in Tanjung Priok district. This research was conducted using survey method with quantitative approach and path analysis technique. The populations in this study were 307 teachers with 75 research samples of teachers selected using simple random sampling technique. Data were obtained through questionnaire and analyzed using path analysis technique. Based on the results of data analysis in this study, it can be concluded: (1) organizational culture has a direct positive influence on teacher work attitude; (2) interpersonal communication also has a positive direct effect on teacher work attitude; (3) organizational culture has a positive direct effect on interpersonal communication. Therefore, work attitude can be developed through the improvement of organizational culture and interpersonal communication.
\end{abstract}

Keywords: Interpersonal Communication, Organizational Culture, Private Junior High School Teachers, Work Attitude

\section{Article Info}


Pengaruh Budaya Organsasi dan Komunikasi Interpersonal Terhadap Sikap Kerja Guru ... | Elfridauli

\section{PENDAHULUAN}

Pendidikan adalah hal utama untuk sebuah perubahan seseorang dari yang tidak bisa menjadi bisa, kemudian pendidikan juga merupakan pemandu bagi karakter seseorang. Pendidikan juga merupakan salah satu yang menjadi penentu pembangunan karakter bangsa, seperti yang dituangkan dalam tujuan pendidikan UU No. 20 tahun 2003 tentang Sistem Pendidikan Nasional, Pasal 3 yang berbunyi: "Tujuan pendidikan nasional adalah mengembangkan potensi peserta didik agar menjadi manusia yang beriman dan bertakwa kepada Tuhan Yang Maha Esa, berakhlak mulia, sehat, berilmu, cakap, kreatif, mandiri, dan menjadi warga negara yang demokratis serta bertanggung jawab".

Salah satu yang berkaitan dengan lembaga pendidikan adalah tenaga pendidik atau yang biasa disebut guru merupakan salah satu ujung tombak tercapainya tujuan pendidikan yang diharapkan dan juga merupakan teladan hidup baik di dalam kelas maupun di luar kelas untuk peserta didik.

Dalam meningkatkan sikap kerja guru yang positif dalam organisasi diperlukannya dukungan dari budaya organisasi seperti selalu ada pelatihan-pelatihan, seminar-seminar dan diskusi mengenai metode mengajar dalam MGMP mata pelajaran. Menurut Darmawan (2013: 143) organisasi dapat berlangsung dan sampai pada visi, misi, tujuannya melalui proses manajemen. Untuk memimpin organisasi, seorang manajer memiliki tugas utama yaitu interpersonal, informasional dan pengambil keputusan.

Setiap organisasi memiliki budaya organisasi yang dapat menjadi ciri khas karakter dari organisasi. Budaya organisasi yang kuat akan menciptakan bentuk perilaku pegawai dan sikap kerja guru, kemudian akan mempengaruhi persaingan antar organisasi. Contohnya dalam organisasi sekolah, bagaimana kuatnya budaya organisasi sebuah sekolah juga akan mempengaruhi sikap guru pada sekolah tersebut. Dengan perilaku dan sikap yang guru tunjukkan akan menjadi ciri khas sebuah sekolah akan semakin meningkatnya kualitas pendidikan. Kemudian organisasi memiliki sebuah komunikasi interpersonal yang berjalan dengan baik sehingga dari komunikasi tersebut akan dapat mempengaruhi sikap kerja guru.

Menurut Sudaryono (2014: 35), perbedaan-perbedaan kultural memiliki dampak besar terhadap kinerja organisasi dan kualitas pengalaman kerja yang dialami oleh para anggota organisasi. Dengan demikian budaya organisasi merupakan suatu kekuatan yang tidak terlihat tetapi dapat mempengaruhi pikiran, perasaan dan tindakan orang-orang yang bekerja dalam suatu organisasi. Sama seperti halnya pribadi setiap manusia memiliki perbedaan sifat, karakter dan nilai-nilai sendiri yang di latarbelakangi oleh latar belakang keluarga, berasal dari suku yang berbeda dan memiliki kebiasaan yang berbeda dalam setiap keluarga dan lingkungan yang membentuk setiap kepribadian seseorang.

Menurut Sugiarta dkk (2013) budaya organisasi berpengaruh positif terhadap kinerja guru, mengikuti program pengembangan kompetensi guru, ikut serta dalam mengembangkan budaya organisasi dalam mentaati peraturan dan program sekolah. Budaya organisasi akan memberikan sebuah nilai-nilai pada setiap guru pada saat bekerja, budaya juga akan memberikan sikap guru pada pekerjaan yang sedang dikerjakan dan diselesaikan. Apakah guru merasa puas dengan pekerjaannya dan dapat membuat bertahan dalam pekerjaannya ini semua juga dipengaruhi oleh budaya sebuah organisasi.

Menurut Ivancevich dkk (2006: 47) budaya organisasi melibatkan harapan, nilainilai dan sikap bersama, dan semua dapat mempengaruhi individu, kelompok dan proses organisasi. Membedakan budaya yang kuat dengan budaya yang lemah sering kali sangat berguna karena budaya yang kuat dicirikan 
oleh adanya pegawai yang memiliki nilai inti bersama. Semakin banyak pegawai yang berbagi dan menerima nilai inti, semakin kuat budaya, dan semakin besar pengaruhnya terhadap sikap kemudian prilaku.

Selain budaya organisasi juga terdapat komunikasi dalam beraktivitas. Budaya dapat membantu seorang pegawai bekerja sesuai dengan budaya organisasi dan peraturanperaturan yang sudah disepakati. Sekalipun budaya organisasi juga sudah dapat membantu tetapi tanpa adanya komunikasi maka nilainilai organisasi tidak dapat tersampaikan dengan maksimal. Menurut Nurrohim dan Anatan (2009: 2) kesuksesan organisasi sangat dipengaruhi oleh kapabilitas dan kompetensi masing-masing individual dan kerjasama antar anggota tim dalam organisasi. Dalam menjalin kerjasama untuk mencapai tujuan tersebut diperlukan adanya komunikasi.

Menurut Tahjudin Nor (2013: 8) pimpinan perusahaan harus benar-benar memperhatikan kepuasan komunikasi organisasi yang ada dalam organisasinya, karena dengan perhatian yang intensif terhadap motivasi kerja pada organisasinya maka diharapkan karyawan akan lebih giat bekerja untuk mewujudkan tujuan organisasinya. Menurut Wiyani (2015: 159) membangun hubungan melalui komunikasi dapat dilakukan secara bertemu dengan bertatap muka untuk bertukar informasi atau tidak perlu bertemu langsung tetapi dengan menggunakan alat elektronik. Komunikasi adalah penggerak organisasi, karena tujuan dari organisasi akan sulit dicapai tanpa komunikasi

Komunikasi dalam proses organisasi menjadi sangat kurang dikarenakan semakin beragamnya setiap pribadi dalam organisasi. Kemudian ditambah lagi semakin meningkatnya teknologi membuat pegawai mengurangi komunikasi secara langsung dan banyak juga yang sibuk kepentingan pribadi. Sedangkan proses organisasi dibutuhkan komunikasi untuk menciptakan sikap kerja guru.

Budaya organisasi dan komunikasi interpersonal memberikan pengaruh positif terhadap kinerja. Budaya organisasi juga dapat meningkatkan kompetensi guru, dengan demikian sikap positif terhadap profesinya atau terhadap pekerjaannya juga dapat meningkat. Menurut Sawaludin (2013: 82) komunikasi interpersonal juga mempengaruhi dimensi sosial dalam organisasi, membuat komunikasi efektif dan guru semakin bekerja keras untuk bertanggung jawab atas pekerjaanya.

Menurut Norlena (2015: 43) sekolah sebagai sebuah organisasi formal, memiliki struktur yang memungkinkan sekolah menjalankan fungsinya sebagai lembaga edukatif yang baik. Didalamnya terdapat sekumpulan manusia yang bekerja bersamasama untuk mencapai suatu tujuan yaitu mencerdaskan generasi bangsa dan adanya prasarana sarana. Menurut Wuryantina (2015: 243) sekolah juga merupakan bentuk keorganisasian moral, berbeda dengan bentuk keorganisasian lain yang berorientasi kepada keuntungan. Hal itu membawa konsekuensi logis bagi setiap komponen sekolah untuk bersinergi, memiliki komitmen yang sama dan menerapkan norma dan nilai yang dianut sekolah demi tercapainya tujuan pendidikan sekolah.

Bekerja bersama-sama juga tidak terlepas dari budaya organisasi, komunikasi interpersonal dan sikap kerja. Banyak guru sudah tidak mengikuti aturan dari budaya organisasi sekolah, banyak juga yang sudah mementingkan diri sendiri dan tidak membangun komunikasi yang aktif dan positif. Kemudian mempengaruhi sikap kerja guru yang sudah mulai menurun, banyak yang memberikan sikap kerja yang bermalasmalasan, sikap kerja yang tidak konsisten dalam membimbing, sikap kerja yang tidak menjadi teladan dan banyak guru mengajar 
hanya untuk sebuah alasan ekonomi. Jika guru mengajar tanpa adanya rasa ketulusan maka semuanya itu menjadi hambar, karena pekerjaan guru bukan kepada sebuah benda tetapi kepada manusia terhadap manusia.

Menurut Librawati dkk (2013) sikap kerja guru akan dapat mempengaruhi keberhasilan dari sebuah sekolah. Bagaimana sikap guru dalam melayani siswa dan bagaimana sikap guru dalam berinteraksi kepada teman sejawat dan kepada pimpinan. Sikap kerja dari seorang guru sangatlah penting karena melalui sikap akan mempengaruhi sikap pribadi, sikap kelompok seperti organisasi dan akan mempengaruhi tujuan organisasi.

Menurut penelitian Karya dkk (2013) sikap kerja guru dalam merespon menyelesaikan tugas dan tanggung jawabnya serta lingkungan kerja tersebut akan dapat berpengaruh terhadap kinerja guru dan berdampak terhadap hasil nilai siswa di sekolah. Sikap kerja guru tersebut meliputi tiga sikap yaitu kepuasan kerja, komitmen organisasi dan keterlibatan kerja. Menurut penelitian Khoiri (2017: 109), kualitas kehidupan kerja berpengaruh langsung positif terhadap sikap kerja, artinya peningkatan kualitas kehidupan kerja mengakibatkan peningkatan sikap kerja guru

Menurut Sugiarta (2012) sikap guru pada pekerjaan harus selalu diupayakan secara positif oleh guru, selain itu hendaknya guru selalu mengupayakan peningkatan pengetahuan dan ketrampilan, dengan cara demikian kemampuan guru akan meningkat dan pendidikan yang berkualitas akan terwujud. Faktor sikap kerja guru dipengaruhi baik dari luar dan dari dalam, artinya bagaimana sikap guru terhadap pekerjaan yang diemban dipengaruhi dari faktor dalam diri guru tersebut. Sedangkan faktor dari luar juga dapat dipengaruhi oleh budaya organisasi dan kualitas komunikasi antar guru tersebut kemudian di bantu oleh kemampuan guru tersebut baik itu pengalaman dan kemampuan

Kecamatan Tanjung Priok adalah salah satu kecamatan di Kotamadya Jakarta Utara, DKI Jakarta. Kecamatan Tanjung Priok memiliki luas $25,13 \mathrm{~km}^{2}$. Menurut data dari Dinas Pendidikan Kotamadya Jakarta Utara Kecamatan Tanjung Priuk memiliki Sekolah Menengah Pertama (SMP) sebanyak 46 sekolah, terdiri dari 35 sekolah swasta dan 11 sekolah negeri, dengan jumlah guru sekitar 635 orang dan peserta didik sekitar 12.506 anak. Khusus untuk SMP swasta jumlah guru ada 307 orang dan jumlah murid sebanyak 6014 anak.

Penelitian ini bertujuan mengetahui ada tidaknya pengaruh langsung budaya organisasi terhadap sikap kerja guru, pengaruh langsung komunikasi interpersonal terhadap sikap kerja guru, pengaruh langsung budaya organsasi terhadap komunikasi interpersonal. Hasil dari penelitian ini diharapkan dapat menjadi acuan kepada guru di SMP Swasta di Kecamatan Tanjung Priok untuk dapat mengevaluasi dan meningkatkan sikap kerja guru.

\section{METODE PENELITIAN}

Penelitian ini akan dilaksanakan di SMP Swasta Kecamatan Tanjung Priok. Penelitian ini dilakukan mulai April sampai Mei 2018.

Metode penelitian yang digunakan adalah metode survey dengan cara mengumpulkan data dengan menyebarkan kuesioner/ angket kepada guru yang hasilnya kemudian diolah melalui untuk mengetahui pengaruh antar variabel yang ada. Penelitian ini dengan menggunakan pendekatan kuantitatif melalui sebab akibat, metode tersebut digunakan untuk menjelaskan pengaruh variabel bebas terhadap variabel terikat pada penelitian ini.

Pada gambar 1 dijelaskan model pengaruh antara variabel eksogen (bebas) 
dengan variabel endogen (terikat) sehingga dapat dipahami dengan mudah dan jelas. Penelitian ini menggunakan paradigma ganda dengan dua variabel independen dan satu dependen.

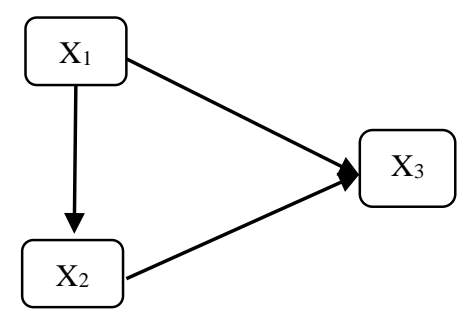

Gambar 1. Paradigma ganda dengan dua variabel independen $X_{1}$ dan $X_{2}$, dan satu variabel dependen $\mathrm{X}_{3}$

Keterangan:

$\mathrm{X}_{1}$ : Budaya Organisasi

$\mathrm{X}_{2}$ : Komunikasi Interpersonal

$\mathrm{X}_{3}$ : Sikap Kerja Guru

Berdasarkan Gambar 1 diatas, sikap kerja guru $\left(\mathrm{X}_{3}\right)$ merupakan variabel terikat. Budaya organisasi $\left(\mathrm{X}_{1}\right)$ dan komunikasi interpersonal $\left(\mathrm{X}_{2}\right)$ merupakan variabel bebas. Konstelasi pengaruh tersebut mengambarkan bahwa budaya organisasi dan komunikasi interpersonal merupakan variabel bebas yang memilki pengaruh terhadap sikap kerja guru.

Populasi dalam penelitian ini berasal dari guru SMP Swasta di Kecamatan Tanjung Priok yang berjumlah 307 guru. Adapun jumlah subjek penelitian yang dijadikan sampel dalam penelitian ini adalah sebanyak 75 orang. Jumlah ini didapat dari rumus penentuan jumlah sampel rumus Slovin, sesuai dengan yang dinyatakan oleh Juliansyah Noor (2011, 158) dengan kesalahan (presisi) 10\% atau tingkat kepercayaan mencapai $90 \%$. Adapun rumus tersebut sebagai berikut:

keterangan:

$$
\mathrm{n}=\frac{N}{1+\left(N e^{2}\right)}
$$

$n=$ Number of Samples (jumlah sampel)

$N=$ Total Populations (jumlah seluruh anggota populasi)

$E=$ error tolerance (toleransi terjadinya galat; taraf signifikansi)
Jika yang kita teliti itu sebanyak 307 orang guru, maka besarnya sampel menurut rumus Slovin ini akan menjadi:

$$
\begin{gathered}
\mathrm{n}=\frac{N}{1+\left(N e^{2}\right)} \\
\mathrm{n}=\frac{307}{1+\left(307(0,1)^{2}\right)} \\
\mathrm{n}=75,429 \approx 75
\end{gathered}
$$

Pengambilan sampel dilakukan dengan cara acak sederhana (simpel random sampling) dimana setiap anggota populasi diberi kesempatan yang sama untuk menjadi sampel penelitian.

Dalam pengumpulan data penelitian digunakan kuisioner yang diberikan kepada responden yaitu para guru SMP Swasta Kecamatan Tanjung Priok. Setiap kuisioner dikembangkan dalam kisi-kisi dari masingmasing variabel penelitian. Untuk kepentingan penelitian ini telah disusun tiga jenis instrument yaitu instrument yang digunakan untuk mengukur variabel budaya organisasi, komunikasi interpersonal dan sikap kerja guru, seperti yang ditunjukkan di Tabel 1, Tabel 2, dan Tabel 3.

Tabel 1. Kisi-kisi Sikap Kerja

\begin{tabular}{lllc}
\hline No & \multicolumn{1}{c}{ Indikator } & Nomor Butir & Jumlah \\
\hline 1 & $\begin{array}{l}\text { Penilaian/respon } \\
\text { pekerjaan }\end{array}$ & $\begin{array}{l}1,2,3,4,5, \\
6,7,8\end{array}$ & 8 \\
& Keterlibatan kerja & $9,10,11,12$, & 6 \\
& & 13,14 & \\
& & $15,16,17,181$ & 8 \\
\hline 3 & Respon terhadap & $9,20,21,22$ & \\
& profesi & $23,24,25,262$ & 5 \\
\hline 4 & Kepercayaan diri & 7 & \\
& & $28,29,30,313$ & 5 \\
\hline 5 & Meningkatkan & 2 & \\
& pengetahuan/keahli & $2,34,35,36$, & 5 \\
& an & 37 & \\
\hline 6 & Ketepatan waktu & $33,39,40,41$, & 8 \\
& & $42,43,44,45$ & \\
\hline 7 & Kualitas pelayanan & 38, & \\
& & &
\end{tabular}


Pengaruh Budaya Organsasi dan Komunikasi Interpersonal Terhadap Sikap Kerja Guru ... | Elfridauli

Tabel 2. Kisi-kisi Budaya Organisasi

\begin{tabular}{|c|c|c|c|}
\hline No & Indikator & Nomor Butir & Jumlah \\
\hline 1 & Peraturan sekolah & $1,2,3,4,5,6$ & 6 \\
\hline 2 & Apresiasi guru & $\begin{array}{l}7,8,9,10,11 \\
12,13,14\end{array}$ & 8 \\
\hline 3 & Program pelatihan & $\begin{array}{l}15,16,17,18 \\
19,20,21,22\end{array}$ & 8 \\
\hline 4 & Gotong Royong & $\begin{array}{l}23,24,25,26, \\
27\end{array}$ & 5 \\
\hline 5 & Prosedur kerja & $\begin{array}{l}28,29,30,31, \\
32\end{array}$ & 5 \\
\hline 6. & Kesetiakawanan & $\begin{array}{l}33,34,35,36, \\
37\end{array}$ & 5 \\
\hline 7 & Komitmen organisasi & $\begin{array}{l}38,39,40,41, \\
42,43,44,45\end{array}$ & 8 \\
\hline
\end{tabular}

Tabel 3. Kisi-kisi Komunikasi Interpersonal

\begin{tabular}{lllc}
\hline No & Indikator & Nomor Butir & Jumlah \\
\hline 1 & Saling mengenal & $1,2,3,4,5$, & 7 \\
& & 6,7 \\
& & \\
\hline 2 & Bekerjasama & $8,9,10,11$, & 5 \\
& & 12 & \\
\hline 3 & Persepsi & $13,14, \quad 15$, & 6 \\
& & $16,17,18$ \\
\hline 4 & Simpati & $19,20,21$, & 5 \\
& & 22,23 & \\
\hline 5 & Komunikatif & $24,25,26$, & 8 \\
& & $27,28, \quad 29$, & \\
& & 30,31 & \\
\hline 6 & Keterbukaan & $32,33,34$, & 8 \\
& & $35,36,37$, & \\
& & 38,39 & \\
\hline 7 & Dukungan & $40,41,42$, & 6 \\
& & $43,44,45$ & \\
\end{tabular}

Konsep yang mendasari penyusunan instrumen bertolak dari indikator-indikator variabel penelitian. Selanjutnya kisi-kisi tersebut dijabarkan menjadi beberapa pernyataan. Alternatif jawaban untuk setiap pernyataan adalah sebagai berikut: (a) sangat sering, (b) sering, (c) jarang, (d) pernah, (e) tidak pernah.

Kategori pernyataan positif diberi nilai: sangat sering $=5$, sering $=4$, jarang $=3$, pernah $=2$, dan tidak pernah $=1$, sedangkan pernyataan negatif diberi nilai sebaliknya yaitu: sangat sering $=1$, sering $=2$, jarang $=3$, pernah $=4$, dan tidak pernah $=5$.

\section{Pengujian Validitas Instrumen}

Uji validitas instrument penelitian bertujuan untuk melihat gambaran tentang kevalidan tiap butir instrument penelitian. Uji validitas butir diperlukan untuk menegaskan bahwa butir-butir instrumen penelitian yang dipakai dalam pengambilan data adalah valid. Secara empiris, hal ini dilakukan dengan melihat koefisien korelasi (pearson product moment) antara butir pertanyaan dengan skor jawaban.

Validitas instrumen diuji dengan rumus product moment sebagai berikut:

$$
r_{x y}=\frac{n\left(\sum X Y\right)-\left(\sum X\right)\left(\sum Y\right)}{\sqrt{\left[n\left(\sum X^{2}\right)-\left(\sum X\right)^{2} \mid n\left(\sum Y^{2}\right)-\left(\sum Y\right)^{2}\right]}}
$$

Keterangan:

$r_{12}$ : Koefisien korelasi product moment

$\Sigma \mathrm{X}$ : Jumlah skor dalam sebaran $\mathrm{X}$

$\Sigma \mathrm{Y}$ : Jumlah skor dalam sebaran $\mathrm{Y}$

$\Sigma X Y$ : Jumlah skor $\mathrm{X}$ dan $\mathrm{Y}$

$\Sigma X^{2}$ : Jumlah hasil yang dikuadratkan dalam sebaran X

$\Sigma \mathrm{Y}^{2}$ : Jumlah hasil yang dikuadratkan dalam sebaran Y

n : Jumlah sampel (responden)

Kriteria validitasnya satu butir instrument penelitian adalah jika nilai $r_{\text {hitung }} \geq$ $r_{\text {tabel. }}$. Besar harga $r_{\text {tabel }}$ ditentukan oleh taraf signifikansi dan derajat kebebasan (dk). Taraf signifikansi ditetapkan pada $\alpha=0,05$. Sedangkan derajat kebebasannya adalah jumlah sampel dikurangi 1(n-1).

\section{Perhitungan Reliabilitas Instrumen}

Perhitungan reliabilitas adalah perhitungan terhadap konsistensi data kuisioner dengan menggunakan rumus Alpha Cronbach. Penggunaan rumus ini disesuaikan dengan teknik skoring yang dilakukan pada saat item dalam instrument. Perhitungan reliabilitas instrumen komunikasi interpersonal sebanyak 45 butir pernyataan. 


\section{Teknik Analisis Data}

Analisis data yang digunakan dalam penelitian ini adalah analisis deskriptif dan inferensial. Analisis deskriptif menyajikan karakteristik data dari masing-masing variabel dalam bentuk penyajian data, ukuran sentral, dan ukuran penyebaran data. Penyajian data ditampilkan dalam bentuk mean, median, dan modus. Sedangkan untuk ukuran sebaran disajikan dalam bentuk varians dan simpangan baku.

Analisis inferensial menggunakan analisis jalur (path analysis). Namun sebelum menggunakan analisis jalur, terlebih dahulu dilakukan uji persyaratan analisis, yaitu uji normalitas, uji signifikansi, dan linearitas. Sedangkan untuk menghitung koefisien jalur dengan menggunakan koefisien korelasi dari masing-masing hubungan kausal.

Variabel dalam penelitian kausal terbagi dua, yaitu variabel endogenus dan variabel eksogenus. Variabel endogenus adalah variabel yang dipengaruhi oleh variabel eksogenus, yang dalam penelitian ini variabel sikap kerja guru $\left(\mathrm{X}_{3}\right)$. Sedangkan variabel eksogenus dalam penelitian ini adalah variabel budaya organisasi $\left(\mathrm{X}_{1}\right)$. Selain berperan sebagai variabel endogenus, variabel komunikasi interpersonal $\left(\mathrm{X}_{2}\right)$ juga sebagai variabel eksogenus

Hipotesis statistik yang digunakan dalam penlitian ini adalah sebagai berikut:

1. Hipotesis pertama terdapat pengaruh langsung positif budaya Organisasi $\left(\mathrm{X}_{1}\right)$ terhadap Sikap Kerja $\left(\mathrm{X}_{3}\right)$.

2. Hipotesis pertama terdapat pengaruh langsung positif Komunikasi Interpersonal $\left(\mathrm{X}_{2}\right)$ terhadap Sikap Kerja $\left(\mathrm{X}_{3}\right)$.

3. Hipotesis pertama terdapat pengaruh langsung positif Budaya Organisasi $\left(\mathrm{X}_{1}\right)$ terhadap Komunikasi Interpersonal $\left(\mathrm{X}_{2}\right)$.

\section{HASIL PENELITIAN DAN \\ PEMBAHASAN \\ Hasil Penelitian \\ Pengujian Persyaratan Analisis}

Analisis statistik parametris digunakan dengan asumsi bahwa data setiap variabel penelitian yang dianalisis terdistribusi secara normal. Pada bagian ini dilakukan proses pengujian persyaratan analisis sebagai syarat agar teknik regresi yang merupakan kelompok statistik parametris dapat diterapkan untuk keperluan uji hipotesis.

Analisis jalur (path analysis) dapat dilakukan apabila estimasi antara variabel eksogen terhadap variabel endogen bersifat linear. Dengan demikian apabila syarat di atas dipenuhi maka analisis regresi dan analisis jalur dapat dilakukan. Syarat analisis jalur adalah sampel penelitian berasal dari populasi yang terdistribusi normal dan pengaruh antara variabel-variabel dalam model harus signifikan dan bersifat linear. Untuk itu pengujian terhadap kedua syarat yang berlaku dalam analisis jalur tersebut perlu dilakukan sebelum proses pengujian model, yang meliputi:

- Uji Normalitas

- Uji Signifikansi dan Linearitas Koefisien Regresi

\section{Uji Normalitas}

Dari hasil perhitungan uji normalitas diperoleh hasil sebagai berikut:

\section{a. Uji Normalitas Galat Taksiran Regresi $\mathrm{X}_{3}$ atas $\mathrm{X}_{1}$}

Hasil analisis data menunjukkan bahwa perhitungan $\mathrm{L}_{\text {hitung }}=0,051$ lebih kecil dari $\mathrm{L}_{\text {tabel }}(\mathrm{n}=75 ; \alpha=0,05)$ sebesar 0,102 . Karena nilai $\mathrm{L}_{\text {hitung }}$ lebih kecil dari $\mathrm{L}_{\text {tabel }}$ maka sebaran data sikap kerja atas budaya organisasi cenderung membentuk kurva normal.

\section{b. Uji Normalitas Galat Taksiran Regresi $\mathbf{X}_{3}$ atas $\mathbf{X}_{2}$}

Hasil analisis data menunjukkan bahwa perhitungan $\mathrm{L}_{\text {hitung }}=0,063$ lebih kecil dari Ltabel $(\mathrm{n}=75 ; \alpha=0,05)$ sebesar 0,102 . Karena 
Pengaruh Budaya Organsasi dan Komunikasi Interpersonal Terhadap Sikap Kerja Guru ... | Elfridauli

nilai $\mathrm{L}_{\text {hitung }}$ lebih kecil dari $\mathrm{L}_{\text {tabel }}$ maka sebaran data sikap kerja atas komunikasi interpersonal cenderung membentuk kurva normal.

\section{c. Uji Normalitas Galat Taksiran Regresi $\mathbf{X}_{2}$ atas $\mathbf{X}_{1}$}

Hasil analisis data menunjukkan bahwa perhitungan $\mathrm{L}_{\text {hitung }}=0,061$ lebih kecil dari Ltabel $(n=75 ; \alpha=0,05)$ sebesar 0,102. Karena nilai $\mathrm{L}_{\text {hitung }}$ lebih kecil dari $\mathrm{L}_{\text {tabel }}$ maka sebaran data komunikasi interpersonal atas budaya organisasi cenderung membentuk kurva normal.

Dengan memperhatikan harga-harga $\mathrm{L}_{\text {hitung }}$ dan $\mathrm{L}_{\text {tabel }}$ pada uji normalitas tersebut dapat disimpulkan bahwa semua data baik sikap kerja atas budaya organisasi, sikap kerja atas komunikasi interpersonal, dan komunikasi interpersonal atas budaya organisasi berasal dari sampel yang berdistribusi normal.

\section{Uji Signifikansi dan Linearitas Regresi}

Uji hipotesis penelitian dilakukan dengan mempertimbangkan hasil analisis regresi dan analisis korelasi. Untuk memprediksi model hubungan variabel satu dengan variabel lain digunakan analisis regresi. Sementara itu, untuk mengetahui pengaruh antar variabel penelitian digunakan analisis korelasi.

Keseluruhan hasil uji signifikansi dan linearitas regresi dirangkum pada tabel 4 .

Tabel 4. Hasil Uji Signifikansi dan Uji Linearitas Regresi

\begin{tabular}{|c|c|c|c|c|c|c|}
\hline \multirow[b]{2}{*}{ Reg } & \multirow[b]{2}{*}{ Persamaan } & \multicolumn{2}{|c|}{ Uji Regresi } & \multicolumn{2}{|c|}{ Uji Linearitas } & \multirow[b]{2}{*}{ Kesimpulan } \\
\hline & & $\mathbf{F}_{\text {hitung }}$ & $\begin{array}{c}\mathbf{F}_{\text {tabel }} \\
\boldsymbol{\alpha}=\mathbf{0 , 0 1}\end{array}$ & $F_{\text {hitung }}$ & $\begin{array}{c}\mathbf{F}_{\text {tabel }} \\
\alpha=0,05\end{array}$ & \\
\hline $\mathrm{X}_{3}$ atas $\mathrm{X}_{1}$ & $\hat{\mathrm{X}}_{3}=33,91+0,56 \mathrm{X}_{1}$ & $45,94 * *$ & 7,00 & $0,90^{\mathrm{ns}}$ & 75 & $\begin{array}{c}\text { Regresi sangat } \\
\text { signifikan/ } \\
\text { Regresi linear }\end{array}$ \\
\hline $\mathrm{X}_{3}$ atas $\mathrm{X}_{2}$ & $\hat{X}_{3}=31,60+0,58 X_{2}$ & $33,63 * *$ & 6,99 & $1,21^{\mathrm{ns}}$ & 75 & $\begin{array}{c}\text { Regresi sangat } \\
\text { signifikan/ } \\
\text { Regresi linear }\end{array}$ \\
\hline $\mathrm{X}_{2}$ atas $\mathrm{X}_{1}$ & $\hat{\mathrm{X}}_{2}=108,81+0,356 \mathrm{X}_{1}$ & $14,67 * *$ & 6,99 & $1,03^{\text {ns }}$ & 75 & $\begin{array}{l}\text { Regresi sangat } \\
\text { signifikan/ } \\
\text { Regresi linear }\end{array}$ \\
\hline
\end{tabular}

Keterangan:
$* * \quad$ : Sangat signifikan
ns $\quad$ : Non signifikan (regresi linear)

Dengan melihat hasil uji signifikansi dari masing-masing variabel didapatkan bahwa model persamaan regresi yang terbentuk antara sikap kerja guru dengan budaya organisasi $\left(\mathrm{X}_{3}\right.$ atas $\left.\mathrm{X}_{1}\right)$, sikap kerja guru atas komunikasi interperonal $\left(\mathrm{X}_{3}\right.$ atas $\mathrm{X}_{2}$ ), dan komunikasi interpersonal atas budaya organisasi $\left(\mathrm{X}_{2}\right.$ atas $\left.\mathrm{X}_{1}\right)$ merupakan regresi yang sangat signifikan karena hasil $F_{\text {hitung }}>$ $\mathrm{Ft}_{\mathrm{abel}}$.

Sementara itu dengan melihat hasil uji linearitas, didapatkan bahwa dalam model persamaan regresi yang terbentuk antara sikap kerja guru dengan budaya organisasi $\left(\mathrm{X}_{3}\right.$ atas
$\mathrm{X}_{1}$ ), sikap kerja guru atas komunikasi interperonal $\left(\mathrm{X}_{3}\right.$ atas $\left.\mathrm{X}_{2}\right)$, dan komunikasi interpersonal atas budaya organisasi $\left(\mathrm{X}_{2}\right.$ atas $\mathrm{X}_{1}$ ), terdapat sebaran titik yang terestimasi membentuk garis linear dapat diterima.

\section{Pengujian Hipotesis}

Berdasarkan hasil analisis sebelumnya kemudian dilakukan pengujian hipotesis dengan menggunakan analisa jalur (path analysis). Hasil analisa jalur pengaruh langsung dari masing-masing variabel ditunjukkan pada Tabel 5.layout tidak/belum tepat 
Kelola: Jurnal Manajemen Pendidikan, Vol. 5, No. 1, Januari-Juni 2018

Tabel 5. Hasil analisa jalur pengaruh langsung masing-masing variabel

\begin{tabular}{ccccc}
\hline Pengaruh & \multirow{2}{*}{ Koefisien Jalur } & \multirow{2}{*}{$\mathfrak{t}_{\text {hitung }}$} & \multicolumn{2}{c}{$\mathrm{t}_{\text {tabel }}$} \\
\cline { 4 - 5 } Langsung & & $5,150^{* *}$ & 1,99 & $\alpha=0,01$ \\
\hline $\mathrm{X}_{1}$ terhadap $\mathrm{X}_{3}$ & 0,470 & $4,041^{* *}$ & 1,99 & 2,65 \\
$\mathrm{X}_{2}$ terhadap $\mathrm{X}_{3}$ & 0,369 & 3,65 & 2,65 \\
$\mathrm{X}_{1}$ terhadap $\mathrm{X}_{2}$ & 0,409 & $3,865^{* *}$ & 1,99 & 2,65 \\
\hline
\end{tabular}

**Koefisien jalur sangat signifikan $(5,150>2,65$ pada $\alpha=0,01)$

Berdasarkan hasil analisa jalur, nilai koefisien jalur pengaruh langsung budaya organisasi $\left(\mathrm{X}_{1}\right)$ terhadap sikap kerja guru $\left(\mathrm{X}_{3}\right)$ sama dengan 0,470 dengan nilai nilai thitung sama dengan 5,150. Nilai tabel untuk $\alpha=0,01$ sebesar 2,65. Karena nilai thitung lebih besar dari pada nilai $\mathrm{t}_{\text {tabel }}$ maka $\mathrm{H}_{0}$ ditolak dan $\mathrm{H}_{1}$ diterima. Hal tersebut menunjukkan bahwa budaya organisasi berpengaruh secara langsung terhadap sikap kerja dapat diterima. Hasil analisis hipotesis pertama memberikan temuan bahwa budaya organisasi berpengaruh secara langsung terhadap sikap kerja. Dengan demikian dapat disimpulkan bahwa sikap kerja dipengaruhi secara langsung oleh budaya organisasi. Semakin baik budaya organisasi mengakibatkan semakin baik sikap kerja.

Dari hasil perhitungan analisis jalur menunjukkan ada pengaruh langsung komunikasi interpersonal terhadap sikap kerja. Nilai koefisien jalur sama dengan 0,369 dan nilai $t_{\text {hitung }}$ sama dengan 4,041. Nilai tabel untuk $\alpha=0,01$ sebesar 2,65. Karena nilai thitung lebih besar dari pada nilai $\mathrm{t}_{\text {tabel }}$ maka $\mathrm{H}_{0}$ ditolak dan $\mathrm{H}_{1}$ diterima. Hal tersebut menunjukkan bahwa komunikasi interpersonal berpengaruh secara langsung terhadap sikap kerja dapat diterima. Hasil analisis hipotesis kedua memberikan temuan bahwa komunikasi interpersonal berpengaruh secara langsung terhadap sikap kerja. Dengan demikian dapat disimpulkan bahwa sikap kerja dipengaruhi secara langsung oleh komunikasi interpersonal. Semakin baik komunikasi interpersonal mengakibatkan semakin baik sikap kerja.

Dari hasil perhitungan analisis jalur menunjukkan ada pengaruh langsung budaya organisasi terhadap komunikasi interpersonal.
Nilai koefisien jalur sama dengan 0,409 dan nilai thitung sama dengan 3,865 . Nilai tabel untuk $\alpha=0,01$ sebesar 2,65. Karena nilai thitung lebih besar dari pada nilai tabel maka $\mathrm{H}_{0}$ ditolak dan $\mathrm{H}_{1}$ diterima. Hal tersebut menunjukkan bahwa budaya organisasi berpengaruh secara langsung terhadap komunikasi interpersonal dapat diterima.

Hasil analisis hipotesis ketiga memberikan temuan bahwa budaya organisasi berpengaruh secara langsung terhadap komunikasi interpersonal. Dengan demikian dapat disimpulkan bahwa komunikasi interpersonal dipengaruhi secara langsung oleh budaya organisasi. Semakin baik budaya organisasi mengakibatkan semakin baik komunikasi interpersonal.

\section{Pembahasan}

Hasil penelitian yang menunjukkan bahwa budaya organisasi berpengaruh secara langsung terhadap sikap kerja di atas membenarkan pandangan Sugiarta dkk (2013) bahwa budaya organisasi akan memberikan sebuah nilai-nilai pada setiap guru pada saat bekerja, budaya juga akan memberikan sikap guru pada pekerjaan yang sedang dikerjakan dan diselesaikan. Hasil di atas juga sejalan dengan teori Ivancevich dkk (2006: 47) bahwa budaya organisasi melibatkan harapan, nilai-nilai dan sikap bersama, dan semua dapat mempengaruhi individu, kelompok dan proses organisasi dan bahwa semakin banyak pegawai yang berbagi dan menerima nilai inti, semakin kuat budaya, dan semakin besar pengaruhnya terhadap sikap kemudian prilaku.

Jika memperhatikan temuan I Wayan Karya dkk (2013) bahwa sikap kerja guru dalam merespon menyelesaikan tugas dan 
Pengaruh Budaya Organsasi dan Komunikasi Interpersonal Terhadap Sikap Kerja Guru ... | Elfridauli

tanggung jawabnya serta lingkungan kerja tersebut akan dapat berpengaruh terhadap kinerja guru maka hasil penelitian di atas memiliki kesejajaran dengan temuan Rahmat (2015) yang menyatakan bahwa budaya organisasi mempunyai hubungan yang signifikan dengan kinerja aparatur pendidikan non formal di wilayah penelitiannya.

Lebih lanjut temuan penelitian ini bahwa komunikasi interpersonal berpengaruh secara langsung terhadap sikap kerja menggarisbawahi pendapat Tahjudin Nor (2013:

8) bahwa pimpinan harus benar-benar memperhatikan kepuasan komunikasi organisasi yang ada dalam organisasinya, karena dengan perhatian yang intensif terhadap motivasi kerja pada organisasinya maka diharapkan karyawan akan lebih giat bekerja untuk mewujudkan tujuan organisasinya. Pun pendapat Wiyani (2015: 159) bahwa komunikasi adalah penggerak organisasi, karena tujuan dari organisasi akan sulit dicapai tanpa komunikasi serta pendapat Sawaludin (2013: 82) bahwa komunikasi interpersonal juga mempengaruhi dimensi sosial dalam organisasi, membuat komunikasi efektif dan guru semakin bekerja keras untuk bertanggung jawab atas pekerjaannya. (bandingkan dengan kajian Hidayat, 2017 tentang komunikasi interpersonal).

\section{SIMPULAN DAN SARAN}

\section{Simpulan}

Berdasarkan hasil penelitian yang dilakukan terhadap guru SMP Swasta di Kecamatan Tanjung Priok, diperoleh kesimpulan penelitian bahwa budaya organisasi berpengaruh langsung terhadap sikap kerja, artinya peningkatan kualitas budaya organisasi menyebabkan peningkatan sikap kerja guru SMP Swasta di Kecamatan Tanjung Priok.

Komunikasi interpersonal berpengaruh langsung terhadap sikap kerja, artinya peningkatan komunikasi interpersonal menyebabkan peningkatan sikap kerja guru SMP Swasta di Kecamatan Tanjung Priok.

Budaya organisasi berpengaruh langsung terhadap komunikasi interpersonal, artinya peningkatan budaya organisasi menyebabkan peningkatan komunikasi interpersonal guru SMP Swasta di Kecamatan Tanjung Priok.

\section{Saran}

Terdapat beberapa saran yang peneliti sampaikan sebagai masukan bagi pihak-pihak terkait antara lain:

$$
\text { Bagi Yayasan SMP swasta di }
$$
kecamatan Tanjung Priok, diharapkan lebih banyak fokus dalam meningkatkan programprogram pelatihan guru dalam mengajar, seminar pendidikan untuk meningkatkan kompetensi guru secara rutin dapat mendorong terwujudnya sikap kerja guru yang maksimal dan berdampak pada kualitas pelayanan sekolah swasta pada dunia pendidikan. Serta memberikan apresiasi kepada guru yang sudah dapat maksimal meningkatkan sikap kerja guru.

Bagi guru SMP swasta di kecamatan Tanjung Priok, diharapkan guru swasta terutama di kecamatan Tanjung Priok dalam bersikap terhadap profesinya sebagai guru dengan pandangan yang positif dan menilai pekerjaan guru sangat istimewa. Dengan memandang pekerjaan guru secara positif maka guru akan memiliki kualitas sikap kerja sesuai dengan tugas pokok guru, kemudian budaya organisasi yang sudah ditetapkan dijadikan sebagai otoritas bagi guru dalam melaksanakan pekerjaannya.

Para peneliti lain agar menindaklanjuti penelitian ini melalui penelitian-penelitian serupa dengan mengembangkan variabelvariabel bebas dan cakupan wilayah penelitian. Hal ini disebabkan masih banyak faktor yang mempengaruhi sikap kerja guru selain budaya organisasi dan komunikasi interpersonal. 
Kelola: Jurnal Manajemen Pendidikan, Vol. 5, No. 1, Januari-Juni 2018

\section{DAFTAR PUSTAKA}

Darmawan, D. 2013. Prinsip-Prinsip Perilaku Organisasi. Surabaya: Pena Semesta.

Hidayat, R. 2017. Peningkatan Aktivitas Komunikasi Interpersonal Dalam Organisasi Melalui Perbaikan Efikasi Diri, Kepemimpinan Dan Kekohesifan Tim. Kelola: Jurnal Manajemen Pendidikan, 4(2), 161-170. -170

Ivancevich, J. M, dkk. 2006. Perilaku dan Manajemen Organisasi. Jakarta: Erlangga.

Karya, I.W., Suhandana, I.G.A, Yudayana, M. 2013. Kontribusi Kompetensi Guru, Sikap Profesi Guru, dan Motivasi Kerja terhadap Kinerja Guru SMA Negeri 1 Sukawati. e-Jurnal Program Pascasarjana Universitas Pendidikan Ganesha, 4, 1-11.

Khoiri, M. 2017. Pengaruh Kualitas Kehidupan Kerja Dan Sikap Kerja Terhadap Kepuasan Kerja Guru Sma Negeri Kecamatan Jekan Raya Kota Palangka Raya Provinsi Kalimantan Tengah. EDUKA Jurnal Pendidikan, Hukum dan Bisnis, 1(5), 96-112.

Librawati, Y. Md., Sunu, IGK. 2013. Analisis Pengaruh Sikap Profesional, Iklim Kerja Sekolah dan Gaya Kepemimpinan Kepala Sekolah Terhadap Kinerja Guru SMP Negeri di Kecamatan Sukawati. e-Jurnal Program Pascasarjana Universitas Pendidikan Ganesha, 4, 13-24

Noor, J. 2011. Metodologi Penelitian. Jakarta: Prenada Media Group.

Norlena, I. 2015. Sekolah Sebagai Organisasi Formal (Hubungan Antar Struktur). Tarbiyah Islamiyah, 5(2), 43-55.

Nurrohim, H. dan Anatan, L. 2009. Efektivitas Komunikasi Dalam Organisasi. Jurnal Manajemen, 7(4), 1-9.
Rahmat, A. 2015. Hubungan Gaya Kepemimpinan Dan Budaya Organisasi Dengan Kinerja Aparatur Pendidikan Nonformal Di Dinas Pendidikan Kota Gorontalo. Kelola: Jurnal Manajemen Pendidikan, 2(2), 173-184.

Sawaludin. 2013. Budaya Organisasi yang Tepat dan Kemampuan Komunikasi Interpersonal Meningkatkan Kinerja Guru. Jurnal Ilmu Ekonomi dan Sosial, 3(1), 73-84.

Sudaryono. 2013. Budaya \& Perilaku Organisasi. Jakarta: LCI.

Sugiarta, M.P, Dantes, N, dan Natajaya, N, 2013. Determinasi Sikap Guru Terhdap Profesinya, Konsep Diri, dan Iklim Kerja Sekolah Terhadap Kinerja Guru Sekolah Dasar di Gugus IV Sukasada, Jurnal Pendidikan Dasar, 3, 1-9.

Sugiarta. 2012. Pengaruh sikap guru terhadap pekerjaan dan pengalaman pendidikan dan pelatihan terhadap kompetensi profesional guru olahraga SMPN SeKabupaten Jepara. Jurnal Manajemen Pendidikan, 1(3), 1-10

Tahjudin Nor, F. 2013. Hubungan Kepuasan Komunikasi Organisasi dengan Motivasi Kerja Karyawan di PT. Srikandi Plastik Sidoarjo. Jurnal EKomunikasi, 1(1), 1-10.

Undang - Undang RI No. 20 Tahun 2003 tentang Sistem Pendidikan Nasional.

Wiyani, N. A. 2015. Etika Profesi Keguruan. Yogyakarta: Gava Media.

Wuryantina, I. 2015. Budaya Organisasi Sekolah dan Motivasi Berprestasi dengan Kinerja Guru pada Sekolah Dasar Negeri Gugus Adiarsa Karawang Barat. Jurnal Pendidikan Dasar, 6(2), 242-253. 